\title{
Measuring Network Competence in BUYER-Supplier Relationships
}

\author{
Gert Human ${ }^{1}$
}

School of Management Studies, University of Cape Town

\begin{abstract}
Managing multiple buyer-seller relationships in business-to-business networks demands an understanding of a firm's competence to manage in an interconnected environment. This paper reports on an attempt to measure network competence by using the NetCompTest scale in businessto-business markets in South Africa. Based on a pilot study refinement, the paper proposes an adjusted measurement scale and details the results of a second round of measurement conducted amongst 495 business-to-business managers in South Africa. The results established partial support for the use of the NetCompTest scale in a South African context, and analysis of variance indicated that some differences in the measurement based on firm and individual characteristics can be observed in the data. The paper assists in theory-building and provides managerial insights for managing buyer-supplier relationships in networks.
\end{abstract}

JEL M12, P47

\section{1 \\ Introduction}

A shift in the strategic context of business, driven by the institutionalisation of new technologies, created a network economy where interconnectivity and co-operation is common practice (Batt \& Purchase, 2004; McGee et al., 2005). Researchers argue (Ford et al., 2004; Freytag \& Ritter, 2005; Johnston et al., 2006; Leek et al., 2003; Ritter et al., 2004) that we have witnessed a change in the nature of industrial structures and customer expectations in business-to-business markets. Instead of straightforward buyer-seller relationships, many modern strategies now involve interconnected and complex structures, rarely to be fully understood from a singular point of view. Batt and Purchase (2004) echo this view and extend the argument by noting that business networks are forming around knowledge bases such that the maximisation of knowledge is obtained through network collaboration rather than through individual business units. Referring specifically to knowledge-driven networks, they noted the increasing reliance on external actors to acquire the desired resources for firms to grow and survive. This observation appears consistent with the resource-dependence perspective (Pfeffer \& Salancik, 2003) as the network now becomes an important strategic resource. Bat and Purchase (2004) conclude that firms seldom survive and prosper solely through their individual efforts. Each firm's performance depends upon the activities and performance of others, and hence upon the nature and quality of the direct and indirect relationships a firm develops with its counterparts. It is not surprising that many authors (Ford et al., 2004; Möller \& Halinen, 1999; Parkhe et al., 2006; Ritter, 1999; Ritter \& Gemünden, 2003a) note that networks have gripped the attention of marketing researchers, and impact on how firms compete. By contrast the notion of networks is not without criticism. Håkansson and Ford (2002) and Ritter et al. (2004) confirm that being embedded a network of ongoing business relationships can both enable and constrain performance. Moreover, a well developed network of relationships may tie a firm into its 
current ways of operating and restrict its ability to change. Managers then face a paradox that a network might be both the source of life for a firm and the cage that imprisons it. Put differently, a network is a way both to influence and to be influenced.

Managing a multiplicity of relationships with many buyers and sellers simultaneously requires certain competencies. Hence, researchers and practitioners alike often look to competencebased theory (CBT) to provide solutions to this problem. An extension of resource-based theory, CBT explains how firms develop strategies to exploit resources in their quest for competitive advantage (Hunt \& Lambe, 2000). Primarily, it suggests that a firm seeks distinctive competencies (Hamel \& Heene, 1994; Hitt \& Ireland, 1986; Sirmon et al., 2007) as key components of their competitive strategy. From a network perspective this raises the question: What is it that any firm needs to do well, or needs to be capable of doing, in order to derive benefit from network relationships? Probing this question has lead business-to-business researchers to consider the competencies required to manage better in business networks. In 1997 Gemünden and Ritter (in Gemünden et al., 1997) introduced the idea of network competence. Described as a higher order construct, network competence refers to the competencies that qualify (enable) firms to manage in networks, as well as the tasks to be executed in managing business relationships in the network. Later, Ritter, Wilkinson and Johnston (2002) suggested that measuring network competence is important and introduced the NetCompTest scale for this purpose. Based on these findings, measuring network competence in business-to-business networks at transactional and account management level is the primary focus of this paper. It implies that the focus is not on strategic relationships of the alliance or joint venture type. Rather, the paper is concerned with the competencies firms might develop to manage better in networks of buyers and sellers, and the context-specific factors that may explain variation in measurement of network competence at this level. However, given the cross-sectional design of the study, it is not always possible to exclude the influences from perceptions based on exposure to strategic types of relationships in survey responses, and this may be amplified by vertical managerial mobility where managers often move freely between strategic and tactical responsibilities in less hierarchical organisations.

The paper briefly motivates the importance of scale validation in a different context from the one in which it was conceived before stating the objectives of the research. The literature review starts by providing literature support for investigating network competence. Then it operationalises the constructs to be employed in this measurement of network competence, as dictated by the NetCompTest scale (Ritter et al., 2002). This operationalisation leads to the construction of the research proposition and hypothesis. The paper then describes the methodology and specifically reports on the procedure for scale refinement based on two consecutive implementations of the scale amongst South African business-to-business managers. Finally, the results are reported and, in addition to suggesting a refined scale, the paper also indentifies individual and firm factors that may impact on the measurement of network competence. The paper concludes with some managerial implications and suggestions for further research.

\section{2}

\section{Research question and objectives}

Various authors (Nairn et al., 2004; Rossiter, 2002; Stacey, 2005; Steenkamp \& Burgess, 2002; Steenkamp \& Trijp, 1997; Sweeney et al., 2000; Wright et al., 2005) allude to the potential contribution of testing emerging theories in management and marketing in a variety of international contexts. More specifically, investigating the validity and reliability of a scale in a context other than the one in which it was conceived, may yield additional insights (Sweeney et al., 2000) that can assist researchers in avoiding the temptation to treat such a construct as an "off-the-shelf" tool. This paper argues that the continued refinement of the NetCompTest scale benefits from a South African application. South Africa is often referred to as an "emerging market" (Burgess 
\& Steenkamp, 2006) ${ }^{2}$ and Khanna et al. (2005) suggest that firms from emerging markets that have strong networks and well-developed social capital may facilitate cooperation in developing knowledge and transferring it locally and/or internationally. Networks may be more difficult to operate in emerging markets because of the limited legal and institutional infrastructure preventing their fluid operation. Therefore, firms in emerging economies may develop network capabilities to overcome their lack of market institutions, and thus gain advantage. This provides further support for the idea of testing the measurement of network competence in South Africa. Moreover, many authors (Bandyopadhyay, 2001; Burgess, 2003b; Cavusgil, 1997; Khanna et al., 2005; Klemz et al., 2005; Sowinski, 2000; Wright et al., 2005) agree that businesses in emerging markets face unique challenges, and the assumption that strategies that are successful in developed markets will work in emerging markets needs to be challenged. Arguably, emerging markets may provide a new context in which to understand the relative strengths and weaknesses of these different perspectives. From these observations the researcher formulates the primary research question of this paper: Is the NetCompTest scale a reliable and valid construct for measuring network competence of B2B firms in the South African context? Observing the performance of the scale in a South African context should provide valuable insights for scale refinement, and contribute towards providing managers with a method for considering their firm's competence to manage in complex business networks.

Given this plethora of support for testing scale performance across various contexts, the primary objective of this paper is to confirm the reliability (Cronbach, 1951; Finn \& Kayande, 1997) and construct validity (Edmundson \& Koch, 1993; Farrell \& Oczkowski, 1997; Lucas et al., 1996; Madden et al., 1986) of the NetCompTest scale as a measure of network competence amongst business-to-business managers in South Africa. De Klerk and Kroon (2008) consider the motivations behind network relationships and report some variations based on firm and individual characteristics. As secondary objectives, and consistent with the findings of De Klerk and Kroon (2008), the paper includes the characteristics suggested by De Klerk and Kroon, but also expands on them by adding both firm and individual characteristics.

\section{3}

\section{The importance of inter- organisational networks and network competence}

Recently, the study of networks in business received significant attention (Dyer \& Hatch, 2006; Golfetto \& Gibbert, 2006; Gwendolyn, 2007; Mesquita et al., 2008) and a rich body of literature is to be found on competencies in business-to-business relationships and buyersupplier networks (Atuahene-Gima, 2005; Awauh, 2001; Bush et al., 2001; Harland \& Knight, 2001; Harmsen \& Jensen, 2004; Ritter, 1999; Ritter et al., 2002; Ritter \& Gemünden, 2003b; Ritter \& Gemünden, 2004; Sanchez \& Heene, 2004; Savolainen, 2002). However, the network approach is not without criticism. For example, Hansen (1999) could only confirm partial support for the notion that an increased number of direct relations in the network results in shorter project completion times. Also, in comparing the views from network and strategy researchers, Baraldi et al. (2007) noted some difficulties with resource-based theory (RBT) to explain competitive behaviour if a network approach is assumed. Given the arguments for and against the notion of buyer-seller networks and specifically network competence, it should be acknowledged that firms are often limited in their ability to develop network competencies with the aim of optimising their network management efforts. Also, Freytag and Ritter (2005) suggest that when the overall collaborative efforts of the network are welldirected, the network may become stronger and the inherent dynamics of business networks may create additional managerial challenges.

In accordance with resource-dependence theory (Forsgren et al., 2005; Pfeffer \& Salancik, 2003), the reliance on other network actors ensures that collaboration between internal and external actors requires expertise 
and competence if the relationship is to be successfully maintained (Ritter et al., 2002). The cited lack of research attention to these actor characteristics (Draulans et al., 2003; Duysters et al., 1999), and specifically the linkage between these characteristics and firm performance, further supports this attempt to consider the measurement of network competence. Arguably, a reliable and valid measure of network competence should provide a useful link to consider its relationship with measures of firm performance. Clearly, the potential importance of a refined scale is evident.

\section{4 \\ Network competence}

Specific reference to competence in a businessto-business (B2B) marketing context is made by Hedaa et al. (2004) when considering ways to express the relationship between a buyer and a seller. Drawing on the contributions from previous authors (Ford et al., 1998; Ford \& Saren, 1996; Håkansson et al., 1976), they note that a supplier needs to have competence, capability and/or ability that are the basis for its interaction with customers. Several of these authors (Ford \& Saren, 1996; Håkansson et al., 1976) also make a distinction between problem-solving ability and transfer ability of a competence. Problem-solving ability is the competence to fulfil a customer's demands and provide value for the customer, and consists of process and product competence, whilst transfer ability describes the competence to transfer the problem-solving ability, such as logistics or market technologies, to a given customer's situation. In turn, Hedaa et al. (2004) noted that a change in orientation from individual relationships towards an understanding of complex systems of relationships (networks) has evolved. This implies that the quality of a solution for customers is measured not only in relation to one problem, but also how well the solution fits into the network. In addition, this evolutionary nature of networks also suggests that limiting measurement of network competence to a specific point in time may not be entirely appropriate. At best, a single measurement can provide a picture at a given point in time. Ideally, a longitudinal research design will facilitate better measurement.

Awauh (2001) argues that most discussions on network competence are very ethnocentric, and the embeddedness of the firm in networks and how that impinges on its competence development is not taken into account. This position results in the introduction (Awauh, 2001) of a modified model of competence development through a network of exchange relationships. Awauh's approach assumes that the firm's competence development is influenced by its interaction with others. This depends on: (a) the transfer of elements, including product/ service exchanges, information exchanges, financial exchanges and social exchanges between interacting parties; (b) mutual learning as a result and driver of exchanges, and (c) mutual adaptations that all parties involved may choose to make. In this continuous cycle the competence of the interacting parties may develop over time. Although each actor has his own interests at heart, and will seek to promote those interests, in a situation where parties understand the interdependence of the network, they may well be mindful of how they conduct themselves to benefit (not harm) the network. Hence, the learning that comes from other parties in the network is very important, since the activities of actors are interconnected. Any actor's inability to meet customers' demands might have an effect on the others with whom they interact, especially their immediate trading partners.

Network competence is considered to be a company-specific ability to handle, use, and exploit inter-organisational relationships (Ritter et al., 2002; Ritter \& Gemünden, 2003b). In addition, it is postulated (Ritter et al., 2002; Ritter \& Gemünden, 2003b) that the availability of resources, a network orientation towards human resource management, the integration of intra-organisational communication, and the openness of corporate culture are antecedents that account for the development and establishment of network competence within the networking company. This recognises that firms are embedded in networks of cooperative and competitive relations with other organisations (Achrol \& Kotler, 1999; Anderson 
et al., 1994; Ford et al., 1998). Within these networks the inter-organisational relationships are long-term arrangements, maintained for some overall functional purpose. However, according to Ritter et al. (2002), there appear to be substantial differences in the ability of firms to deal with networks - providing more support for measuring network competence.

\section{5}

\section{Components of network competence}

Ritter et al. (2002) describe network competence as an embedded firm construct because the ability to manage in networks is inseparable from the company itself. The term competence is used to describe preconditions (i.e., resources, skills, or knowledge) necessary to perform certain tasks with respect to business networks. In this conceptualisation competence is also recognised as a process, and the execution of tasks to develop and maintain network relationships is incorporated. Hence, their definition (Ritter et al., 2002) seeks to include having both the necessary knowledge, skills, resources, and the execution of the network tasks effectively. In this paper, the former (resources, skills, or knowledge) are collectively referred to as "network management qualifications", while the latter (the execution of tasks) is referred to "task execution". To be consistent, this paper will retain the reference to network work management qualifications, while the term "network management tasks" will be adopted to replace "task execution".

\subsection{Network management tasks}

The contributions of multiple authors (Hakansson \& Ford, 2002; Möller \& Halinen, 1999; Wilkinson \& Young, 2002) suggest that a distinction between tasks which are relevant to managing a single relationship and tasks which are necessary to manage a portfolio of relationships is useful. Three different types of relationship-specific tasks (initiation of relationships, exchanging products and services and coordinating dyadic relationships) are supplemented with "adaptations" from both sides of the dyad to contribute to that specific relationship. This addition is well supported in recent research by Fang (2008) and Palmatier (2007), who refer to it as relationship-specific investments (RSI). For the purpose of this study the researcher maintains the reference to relationship-specific tasks. In terms of crossrelational tasks, Ritter et al. (2002) draw on the widely recognised managerial tasks of planning, organising, staffing and controlling in general management literature (Carroll \& Gillen, 1987; Fottler, 1981; Lichtenstein \& Dade, 2007; Wernerfelt, 1989; Witzel, 2002) to support their approach. These tasks are present in all relationship management activities and partially reflect the firm's competence in network management. The reference to cross-relational tasks is retained for this study.

\subsection{Network management qualifications}

Ritter et al. (2002) also make a distinction between specialist (also referred to as "special") qualifications and social qualifications. Specialist qualifications deal with the "technical side of the relationship" and include political, legal and economic specialties, as well as knowledge about other actors. In turn, these imply information about the operations of network partners and their resources. Social qualifications refer to how organisation members behave in interorganisational settings. They include aspects such as communication ability, extraversion, conflict management skills, empathy, emotional stability, self-reflectiveness, sense of justice, and cooperativeness. Such aspects reflect the interpersonal interactions between businessto-business actors in a network, and are considered important determinants of network competence. The term "specialist qualifications" is maintained for this study and is also referred to as "special qualifications". Similarly, the term "social qualifications" is preserved without adjustment.

In conclusion, Ritter et al.'s (2002) definition of network competence refers to the sum of how well the firm is qualified to operate in a network or in several networks, combined with how well network management tasks can be executed. Network qualification suggests a collection of resources, whilst network management 
task execution refers to the ability to employ these resources to operate synergistically within a network. Combined, they constitute a competence called network competence (Figure 1).

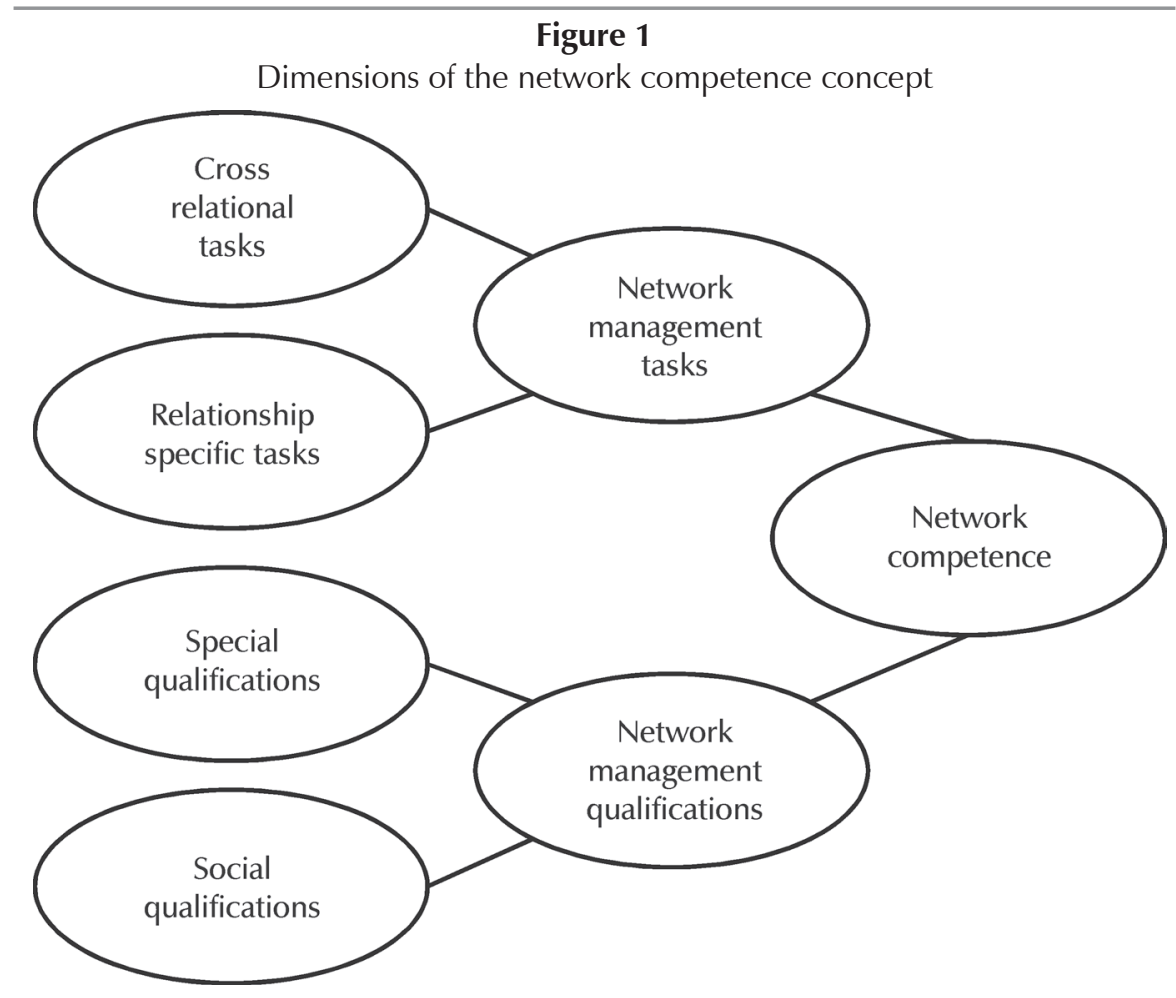

Source: Adapted from Ritter, Wilkinson \& Johnston (2002) and Ritter \& Gemünden (2003b)

Figure 1 depicts the dimensions that Ritter et al. (2002) employ to develop the NetCompTest scale to measure network competence. In their research a battery of 78 statements was administered to a sample of 405 MBA students from Germany, the United Kingdom and Malaysia. The result was a refined 22-items scale corresponding to four dimensions as depicted by the model (Figure 1) and all the dimensions yielded Cronbach alpha coefficients higher than 0.7 , indicating good reliability. The scale primarily measures an individual's responses to the four first order dimensions of crossrelational tasks, relationship-specific tasks, special qualifications and social qualifications. Therefore, in this study it was decided to consider the contribution of each first order item on network competence. Following this notion that network competence can be measured by using four dimensions, the primary research proposition for this study is formulated as follows:

The NetCompTest scale demonstrates sufficient internal reliability and construct validity to measure network competence in a South African business-to-business context.

In addition to describing network competence as an embedded firm construct, Ritter et al. (2002) argue that it is a firm-wide responsibility, and therefore subject to the characteristics of the firm (also referred to as organisational characteristics) and the individuals (also referred to as personal characteristics) within the firm. In terms of the individuals within the firm, there is ample support from social network theory (Gwendolyn, 2007; Iacobucci \& Hopkins, 1992; Moller \& Rajala, 2007; Ross \& Robertson, 2007; van der Merwe et al., 2007) that suggests the individuals play a significant 
role in network management. Similarly, the literature exhibits support for the idea that firm (referred to as "actors" in a network context) characteristics (Draulans et al., 2003; Duysters et al., 1999) play an important part in network management. More recently, and more specific to South Africa, De Klerk and Kroon (2008), in their analysis of the motivations and/or value drivers behind the participation in networks, include both firm characteristics (such as firm size and primary industry type), and individual characteristics (such as age, education and experience) as potential sources of variance. Consistent with De Klerk and Kroon (2008) and Zahra and George (2002), this paper will also attempt to test for variation based on these characteristics, except that in this study the variance in network competence is considered. Therefore, as a secondary objective, the paper includes the De Klerk and Kroon characteristics, but also expands on them by adding more firm characteristics (firm type, ownership, and more measures of firm size) and more individual characteristics (functionality, managerial level and ethnicity). The inclusion of these characteristics facilitates the formulation of two more hypotheses:

H1: There is no significant difference in the overall network competence scores produced by the NetCompTest scale based on firm factors in a South African business-to-business context.

H2: There is no significant difference in the overall network competence scores produced by the NetCompTest scale based on individual factors in a South African business-to-business context.

\section{6}

\section{Methodology}

\subsection{The sample and data collection}

The empirical design of the research included a pilot study for the purposes of scale refinement, and a final study with a larger sample to confirm the performance of the scale in a South African context. The sample frame was defined as managers responsible for the creation and/or maintenance of business-to-business relationships. This sample frame was used for both the pilot study and the final study. Because a single inclusive database of all business-tobusiness managers is not available in South Africa, a non-probability purposive sampling method was employed for both the pilot and the final study. This is a limitation of the study as it is not representative of all business-tobusiness managers, but it does exclude nonbusiness-to-business managers or alternatively exclusive business-to-consumer managers. The respondents were obtained from a personal database of the researcher, which includes firms with an exclusive business-to-business market focus, as well as firms that serve both business and consumer markets.

The data were collected by means of a structured questionnaire which contained the NetCompTest scale and the demographic variables relating to firm and individual respondents' characteristics. In the case of the pilot study, the original 22-item NetCompTest was used with only editorial adjustments to reflect a South African context. For the final study the refined scale that resulted from the pilot study was included. For both samples a multi-respondent method was employed. This means that a single firm might have more than one respondent. The pilot study yielded 268 respondents from 30 firms, whilst the final study yielded 495 from 100 firms. This is regarded as satisfactory as the pilot study represented more than 30 per cent of the respondents in the final study.

\subsection{Data analysis}

Because the primary objective of the study was to explore the appropriateness of the network competence scale under South African conditions, the analysis focused on internal reliability and construct validity in an attempt to gauge the usefulness of the scale in a particular context. Reliability, referring to the ability of the measurement construct to produce the same or similar results with repeated measurements, was considered through Cronbach's alpha coefficient and item-to-total correlations. According to Cooper and Schindler (2006), reliability can be defined as the extent to which a measurement is free of variable errors. Thus, the reliability 
indicates the precision of measurement scores or how accurately such scores will be reproduced if the measurement is repeated. A generally accepted approach (Jarvis et al., 2003; Locke, 2000; Ruekert \& Churchill Jr, 1984) for assessing the reliability is to determine the portion of the systematic variation in a measurement scale. In order to achieve this, the association between scores obtained from two scales, when one scale is a similar replicated version of the other, is determined. If the scores derived from the two scales are high, the scales are consistent in yielding the same result, and are therefore reliable. A correlation coefficient is commonly used for this measurement, and according to McDaniel and Gates (2006), most emphasis in modern social science has been placed on internal consistency and reliability. In this case, item scores obtained from administering the scale are split in half and the resulting halves are correlated. It follows that item-to-total correlations are employed to measure the correlation of each item to the total. Although this approach might be useful, it is also limited in the way that the halves are obtained. This problem can be overcome by using Cronbach's alpha coefficient. Cronbach's alpha is a mean reliability coefficient calculated from all possible split-half partitions of the measurement scale.

Construct validity was considered through the use of confirmatory factor analysis in Structural Equation Modeling (SEM) for the pilot and the final study. Validity refers to the extent to which differences in the observed scale scores reflect true differences in the characteristics or constructs being measured (Bagozzi \& Foxall, 1995; Locke, 2000; Ruekert \& Churchill Jr, 1984; Stacey, 2005). Thus, validity (like reliability) is concerned with error. In the case of validity, consistent or systematic error, rather than variable error, is under consideration. Confirmatory factor analysis differs philosophically from exploratory factor analysis in that the researcher is required to specify the number of factors and which factors will load onto variables. Structural Equation Modeling is then employed to test the extent to which the researcher's a priori pattern is represented in the data (Hair $\mathrm{Jr}$ et al., 2007). SEM not only allows the researcher the opportunity to consider multiple observed variables, but it also explicitly takes measurement error into account and gives greater recognition to measurement constructs. In addition, it also provides for considering differences between constructs simultaneously (Bagozzi, 1994; Chin, 1998; Netermeyer et al., 1991; Netemeyer et al., 2004).

Finally, differences between multiple groups were considered through analysis of variance (ANOVA) and in cases where only two groups are compared the t-statistic (t-test) was employed. These remain the most common measures to consider differences between groups. ANOVA employs the mean square between groups and the mean square error to compute an F-statistic, while the t-statistic indicates how extreme a statistical estimate is by subtracting the hypothesised value from the statistical estimate and then dividing it by the estimated standard error. The approach is formalised by comparing the t-statistic to a percentile from the $\mathrm{t}$-distribution.

\section{7 \\ Results}

This section briefly describes the demographics of both samples before it reports the findings of the pilot study which resulted in a refined scale. The remaining sections are allocated to reporting the results of the confirmatory factor analysis based on the refined scale in the final study. In conclusion, the results of the ANOVA analysis are reported to consider differences between groups based on firm and individual characteristics.

Comparing the sample characteristics (Table 1) revealed significant sample equivalence and the pilot sample is considered representative of the intended final sample. Some key observations regarding the samples are: The majority of respondents in both samples were from South African-owned firms and derived the majority of their sales from business activities in South Africa. In both samples the primary sectors (based on the standard industrial classification by the Department of Trade and Industry, 2005) Wholesale and Retail Trade, Financial Services, Manufacturing and Construction was 
best represented. Cumulatively, the majority of respondents in both samples indicated that they held either top or middle management positions. Also, in both samples, Sales, Operations and Marketing were the best represented functional areas of deployment. A wide spectrum of large and smaller firms ${ }^{3}$ were included in both samples as $68-70$ per cent of the firms employ fewer than 300 people, while up to 13 per cent have more than 5000 employees, and more than 30 per cent of the firms have an annual turnover of more than R50 million. Finally, in both samples a significant portion (34.1 per cent and 50 per cent for the pilot and final studies, respectively) of the respondents was younger than 40 years, and the average age of both samples was between 36 and 40 years. Also, in both samples the majority of respondents ( 73 per cent and 71 per cent, respectively) were males.

Table 1

Comparative sample characteristic for pilot and final studies

\begin{tabular}{|c|c|c|}
\hline Characteristic & Pilot* & Final* \\
\hline $\mathrm{N}$ & 268 & 495 \\
\hline Firms represented & 31 & 100 \\
\hline$\%$ Private sector firms & $93 \%$ & $92 \%$ \\
\hline$\%$ South African firms & $77 \%$ & $77 \%$ \\
\hline$\%$ of sales generated from South African Markets & $88 \%$ & $84 \%$ \\
\hline \multicolumn{3}{|l|}{ Major Standard Industrial Classification (SIC) categories: } \\
\hline Wholesale and retail trade & $22 \%$ & $21 \%$ \\
\hline Financial services & $18 \%$ & $21 \%$ \\
\hline Manufacturing & $15 \%$ & $18 \%$ \\
\hline Construction & $12 \%$ & $12 \%$ \\
\hline Other (6 categories) & $33 \%$ & $28 \%$ \\
\hline \multicolumn{3}{|l|}{ Managerial position: } \\
\hline$\%$ Top management & $51 \%$ & $48 \%$ \\
\hline Cumulative $\%$ top and middle management & $86 \%$ & $84 \%$ \\
\hline \multicolumn{3}{|l|}{ Functional deployment: } \\
\hline$\%$ in Marketing and sales management & $28 \%$ & $30 \%$ \\
\hline$\%$ in Operations management & $36 \%$ & $15 \%$ \\
\hline \multicolumn{3}{|l|}{ Firm size by number of employees: } \\
\hline$\%<300$ & $70 \%$ & $68 \%$ \\
\hline$\%>5000$ & $13 \%$ & $12 \%$ \\
\hline \multicolumn{3}{|l|}{ Firm size by annual turnover: } \\
\hline$\%<$ R10 million & $42 \%$ & $36 \%$ \\
\hline$\%>$ R50 million & $32 \%$ & $33 \%$ \\
\hline Average respondent age (years) & $36-40$ & $36-40$ \\
\hline$\%$ Younger than 40 years & $34 \%$ & $50 \%$ \\
\hline$\%$ Male respondents & $73 \%$ & $71 \%$ \\
\hline$\%$ Female respondents & $27 \%$ & $29 \%$ \\
\hline \multicolumn{3}{|l|}{ Ethnicity: } \\
\hline$\%$ Black & $10 \%$ & $10 \%$ \\
\hline$\%$ White & $58 \%$ & $55 \%$ \\
\hline$\%$ Coloured & $14 \%$ & $14 \%$ \\
\hline
\end{tabular}

\footnotetext{
* Rounded to the nearest 10 .
} 


\subsection{Pilot study results}

\subsubsection{Reliability (pilot study)}

As indicated, the reliability of the scale used in the pilot study was considered through the use of the Cronbach's alpha coefficient. The overall Cronbach alpha for the 22-item scale exceeded $0.7(\alpha=0.874)$, indicating good reliability. However, item 6 and item 7 produced unsatisfactory $(<0.3)$ item-to-total correlations (item $6=0.289$; item $7=0.266$ ). This suggests that these two items may be eliminated from the scale without affecting the overall reliability of the scale.

\subsubsection{Validity (pilot study)}

The data were subjected to confirmatory factor analysis (using Lisrel 8.8) in order to consider each of the dimensions separately before attempting a composite model fit. Based on the recommendation by Hair et al. (2006), factor loadings of 0.5 and higher were considered significant for the analysis. The results of this analysis for each dimension (factor) of network competence are as follows:

The "cross-relational tasks" dimension did not yield an a priori good fit, and had a root mean square error of approximation (RMSEA) of 0.15 which improved if item 2 was eliminated. In the case of the "relational-specific tasks" dimension, an a priori weak fit (RMSEA $=0.25$ ) was also observed, but improved (RMSEA = $0.074, \chi^{2}=0.088$ ) after items 10 and 11 were dropped from the scale. In addition, the "specialist qualifications" dimension yielded a poor a priori fit (RMSEA $=0.32$ ), and dropping item 12 (as suggested by the EFA) led to a saturated model with no degrees of freedom. However, adding item 16 yielded a much improved fit $(\mathrm{RMSAE}=0.018)$. Finally, the "social qualification" dimension also yielded a weak a priori fit (RMSEA $=0.10$ ) which can be significantly enhanced (RMSEA $=0.02$ ) by dropping items 16,17 and 22 . This analysis resulted in the removal of items $2,10,11,12,17$ and 22 , while item 16 was allowed to load on to the "special qualifications" dimension.

Table 2

Adjusted 15-item scale for network competence

\begin{tabular}{|c|l|}
\hline $\begin{array}{c}\text { Network } \\
\text { management }\end{array}$ & $\begin{array}{l}\text { Cross-relational tasks } \\
\text { 1. We evaluate the way our relationship with each business partner depends on our } \\
\text { relationship with other business partners. }\end{array}$ \\
2. We organise regular meetings among those in our firm involved in relationships with our \\
business partners. \\
3. We assign people to each relationship with our business partners. \\
4. We assign responsibility to people for each relationship with our business partners. \\
Relationship-specific tasks \\
$\begin{array}{l}\text { 5. We use organisations apart from our existing business partners, to identify potential } \\
\text { technical partners (e.g. Chambers of commerce, consultants, industry associations, } \\
\text { government organisations). }\end{array}$ \\
$\begin{array}{l}\text { 6. We visit industrial fairs and exhibitions to identify potential business partners. } \\
\text { 7. We look at company advertisements in specialised journals to identify potential business } \\
\text { partners. } \\
\text { management } \\
\text { qualifications }\end{array}$ & $\begin{array}{l}\text { Se discuss ways of collaborating with people from our business partners. } \\
\text { 9. Our business partners (they) have good knowledge about the way our firm works. } \\
\text { 10. They have good knowledge about the way "our technical partners" firms work. } \\
\text { 11. They are experienced in dealing with "technical partners". } \\
\text { Social qualifications } \\
\text { 12. They mix well with other people. } \\
\text { 13. They easily sense potential conflict. } \\
\text { 14. They can work out constructive solutions when there is conflict. } \\
\text { 15. They can easily put themselves in another person's position. }\end{array}$ \\
\hline
\end{tabular}


This manipulation suggested an a priori structure containing the four first-order factors, as suggested by Ritter et al. (2002), and achieved an acceptable fit $\left(\chi^{2}=232.30 ; \mathrm{df}=110 ; \mathrm{p}=0.000\right.$; RMSEA $=0.056$ ). The result of this analysis was a revised scale presented in Table 2 .

\subsection{Final study results}

The original NetcompTest scale, having been adjusted to a 15 -item scale, was subjected to another round of testing with a larger sample. This round also employed a multi-respondent, non-probability sample of 495 respondents from 100 business-to-business firms in South Africa. The refined scale used in the second round of analysis was also subjected to reliability and validity testing through confirmatory factor analysis (CFA) using LISREL (Jöreskog \& Sörbom, 1993; Jöreskog \& Sörbom, 1999).

\subsubsection{Reliability (final study)}

In this round $(\mathrm{N}=495)$ the overall Cronbach's alpha coefficient $(\alpha)$ for the refined scale exceeded $0.7(\alpha=0.812)$, indicating good reliability. However, it was noted that items 1 $(0.180)$ and $8(0.018)$ had weak $(<0.3)$ itemto-total correlations, indicating that these items may be removed from the scale without influencing the total reliability of the scale. This appeared inconsistent with the findings of the first round administration and therefore these items were retained for the construct validity analysis.

\subsubsection{Validity (final study)}

All the items exhibit significant loadings $(>0.5)$, and by using the robust maximum likelihood estimation method the confirmatory factor analysis yielded acceptable fit statistics: $\chi^{2}=$ $44.0 ; \mathrm{df}=29 ; \mathrm{p}=0.03 ; \mathrm{RMSEA}=0.033$. Other notable "goodness-of-fit" statistics for this model include: $\mathrm{NFI}=0.97, \mathrm{CFI}=0.99, \mathrm{GFI}=$ 0.98 and AGFI $=0.96$. On the basis of both the reliability and validity analysis, the first research proposition could only be partially supported as the reliability of the measurement is in doubt.

\subsection{Individual and firm factors}

Individual and firm factors that were expected to have an influence on the overall network competence scores (and its four latent variables separately) were included in this analysis. Firm factors included firm type, firm nationality, economic sector, black economic empowerment (BEE), and firm size. Individual factors included managerial function, managerial level, respondent age, respondent nationality, ethnicity, and gender. Table 3 reports these results. In terms of firm type (referring to whether it is a for-profit company, a not-forprofit organisation, or a government institution), no significant differences were observed to the overall network competence score, and the means of latent variables $(\mathrm{p}<0.05$ is regarded as significant).

Similarly, no significant differences in the mean scores for latent variables and the overall network competence score were observed based on firm nationality (referring to whether a firm is fully South African-owned, partially foreignowned, or fully foreign-owned). Respondents were also asked whether the majority of their sales originated in domestic or international markets. Levene's test for equality of variances was employed to compare these means for each latent variable and the overall network competences score. The data suggested that in the case of the "special qualifications" dimension $(F=0.713 ; p=0.399)$ and the "social qualification" dimension $(\mathrm{F}=2.068$; $\mathrm{p}=0.152)$ the means for these groups are different. However, a t-test for equality of means indicated that these $(\mathrm{t}=0.525$ and $\mathrm{t}=0.803$, respectively) differences are not significant at the 95 per cent level. 


\section{Table 3}

ANOVA results (F-statistic) for firm and individual factors

\begin{tabular}{|c|c|c|c|c|c|}
\hline & $\begin{array}{l}\text { Cross- } \\
\text { relational } \\
\text { tasks }\end{array}$ & $\begin{array}{l}\text { Relationship } \\
\text { specific tasks }\end{array}$ & $\begin{array}{c}\text { Special } \\
\text { qualifications }\end{array}$ & $\begin{array}{c}\text { Social } \\
\text { qualifications }\end{array}$ & $\begin{array}{c}\text { Overall } \\
\text { network } \\
\text { competence } \\
\text { score }\end{array}$ \\
\hline \multicolumn{6}{|l|}{ Organisational factors: } \\
\hline \multirow[t]{2}{*}{ Firm type } & 1.779 & 1.030 & 0.980 & 0.494 & 0.880 \\
\hline & $(0.171)$ & $(0.359)$ & $(0.907)$ & $(0.611)$ & $(0.416)$ \\
\hline \multirow[t]{2}{*}{ Ownership } & 0.097 & 0.809 & 0.716 & 0.792 & 0.189 \\
\hline & $(0.336)$ & $(0.447)$ & $(0.490)$ & $(0.454)$ & $(0.828)$ \\
\hline \multirow[t]{2}{*}{ SIC category } & $2.533^{*}$ & 0.756 & 1.295 & 1.397 & 1.586 \\
\hline & $(0.050)$ & $(0.684)$ & $(0.225)$ & $(0.177)$ & $(0.103)$ \\
\hline \multirow[t]{2}{*}{ Firm size: Employees } & $3.284^{*}$ & 1.008 & 0.357 & 0.643 & 1.344 \\
\hline & $(0.004)$ & $(0.420)$ & $(0.905)$ & $(0.696)$ & $(0.238)$ \\
\hline \multirow[t]{2}{*}{ Firm size: Sales } & 1.514 & 0.460 & 0.416 & 0.520 & 0.368 \\
\hline & $(0.199)$ & $(0.765)$ & $(0.797)$ & $(0.721)$ & $(0.831)$ \\
\hline \multicolumn{6}{|l|}{ Individual factors: } \\
\hline \multirow[t]{2}{*}{ Functional deployment } & 1.183 & $2.331^{*}$ & 1.477 & 0.949 & $1.906^{*}$ \\
\hline & $(0.299)$ & $(0.010)$ & $(0.140)$ & $(0.494)$ & $(0.039)$ \\
\hline \multirow[t]{2}{*}{ Managerial level } & 1.065 & 2.295 & 1.641 & 0.137 & 1.021 \\
\hline & $(0.346)$ & $(0.103)$ & $(0.196)$ & $(0.872)$ & $(0.362)$ \\
\hline \multirow[t]{2}{*}{ Age } & 1.194 & $3.343^{*}$ & $2.305^{*}$ & 1.456 & 1.399 \\
\hline & $(0.310)$ & $(0.003)$ & $(0.035)$ & $(0.194)$ & $(0.215)$ \\
\hline \multirow[t]{2}{*}{ Race } & 0.811 & $2.724^{*}$ & 0.938 & 1.778 & 2.029 \\
\hline & $(0.062)$ & $(0.014)$ & $(0.468)$ & $(0.104)$ & $(0.062)$ \\
\hline
\end{tabular}

Significance $(p)$ is in parentheses

* Significant at 95 per cent $(p<0.05)$ level

It was expected that the mean network competence scores would differ significantly across industries as defined by the standard industrial classification (SIC) of all economic activity in South Africa. Surprisingly, with the exception of one dimension (cross-relational tasks), no significant differences in means scores were found. Further analysis revealed that for cross-relational tasks the mean scores of "private household exterritorial organisations, representatives of foreign governments and other activities not adequately defined" appeared to differ significantly from the means obtained from other categories. According to the Cohen criteria, these differences represent a medium (0.06) to large (0.14) effect at 0.09886 .

In South Africa the recent past has seen the introduction of black economic empowerment legislation to ensure transformation in the economy. This means that many firms are required to establish relationships with blackowned companies - essentially expanding their business networks. Hence, it was expected that the perceived level of BEE compliance would correlate positively with network competence. Correlation analysis revealed that overall network competence $(\mathrm{r}=0.231 ; \mathrm{p}=0.000)$, specialist qualifications $(\mathrm{r}=0.267 ; \mathrm{p}=0.000)$, 
and social qualifications $(\mathrm{r}=0.263$; $\mathrm{p}=$ 0.000 ) correlate significantly positively with perceived BEE compliance at the 99 per cent confidence level. Both the remaining dependent variables (cross-relational tasks and relationship-specific tasks) also exhibit positive, but weaker, correlations with perceived BEE compliance. This result suggests that increased levels of network competence may be associated with increased levels of BEE compliance.

The final firm variable included in the study is firm size as measured by the number of employees and sales. For firm size by number of employees, the ANOVA analysis revealed no significant difference between groups, with the exception of the cross-relational tasks variable. For this variable $(\mathrm{F}=3.284, \mathrm{df}=6, \mathrm{p}=0.004)$ significant differences were found between firms having more than 5000 employees and firms with fewer than 50 employees, as well as for firms with between 300 and 1000 employees. For firm size measured by annual sales, no significant difference (ANOVA) between groups was found. These findings suggest that, as expected, firm size might not play a significant role in measuring network competence.

Similar to firm factors, individual factors (respondent) were also analysed for differences between groups. In considering the functional deployment of respondents, the analysis indicates that there are statistically significant differences in network competence according to managerial position for two of the latent variables in the network competence scale. These differences were observed for the relationship-specific tasks dimension $(\mathrm{p}=0.010)$, as well as for the overall network competence score $(\mathrm{p}=0.039)$. This finding suggests that managers from human resources sections score the relationship-specific competence of the firm differently from how managers in the marketing and information sections do it. There is also a difference between the mean scores of HR managers and sales managers on the overall network competence for the firm. This finding is viewed with scepticism as the number of HR managers in the sample is very small (2.6 per cent).

No significant difference between groups according to managerial level was found, suggesting that managerial seniority has little impact on the measure of perceived network competence. In contrast, respondent age appeared to contain some significant differences between groups for the relationship-specific dimension $(\mathrm{F}=3.343, \mathrm{p}=0.003)$ and special qualifications $(\mathrm{F}=2.305, \mathrm{p}=0.035)$ dimension. This result suggests that the respondents in the age category 46-50 years and respondents in the age categories younger than 45 years seem to respond differently. The generalisation of this finding is limited as only 8.2 per cent of the sample came from the 46 to 50 age category. Interestingly, a t-test for equality of means revealed that the differences between South Africans and non-South Africans on four out of the five dimensions (including the overall network competence score) are significant. However, only 7.5 per cent of the sample consisted of non-SA citizens and stronger evidence may be required. It was expected that within-country diversity (Burgess, 2003a) might reveal different network competence scores based on ethnicity. Therefore, it was somewhat surprising to find that no significant difference was observed for four out of five (including the overall network competence) dimensions based on ethnicity. Finally, t-test analysis also revealed no significant difference in the network competence scores between males and females.

These findings indicate that for most of the variables there appear to be no significant differences in the network competence scores based on various individual and firm variables. However, some significant differences in terms of industry type, firm size, functional area, respondent age and nationality were found, and $\mathrm{H} 1$ and $\mathrm{H} 2$ could not be accepted, suggesting that network competence scores might be influenced by variations in individual and firm characteristics.

\section{8 \\ Discussion and managerial implications}

The attention that buyer-seller networks receive internationally is well documented (Dyer \& Hatch, 2006; Ford et al., 2005; Freytag \& Ritter, 2005; Håkansson, 2006; Håkansson \& Ford, 2002; Leek et al., 2003; Palmer, 2001; Parkhe et 
al., 2006; Walter et al., 2001). The same cannot be said for South African business-to-business networks and this paper seeks to contribute towards filling that gap. Particularly the notion of network competencies poses interesting questions, including the challenge of creating and maintaining competitive advantage in an increasingly interconnected (networked) environment. Research by Golfetto and Gibbert (2006) notes that existing work on the role of competencies in industrial marketing firstly focuses on established approaches to deal with competencies as inputs to organisational processes and the consequent attempts to establish how far marketing competencies such as customer relationship management, channel design, etc. lead to superior financial returns. Secondly, as supported by studies by De Klerk and Kroon (2008) and Ritter and Gemünden (2004), it also focuses on the marketing of competencies as a source for customer value. It is therefore unlikely that "network competence" will escape the competitive advantage debate, the reason being that a key question from a practitioner point-of-view remains: For the firm not only to manage a network, but to be efficient in managing within a network, which competencies should be emphasised and developed? In turn, this implies that some measurement of existing competencies is required and the idea to measure network competence contributes to answering this question. This paper established partial support for the ability of the NetCompTest scale to assist in such a measurement. Equally important is that the measurement done in this study suffers from a number of limitations, to be discussed in the following section. Even so, the Ritter et al. (2002) and Ritter and Gemünden (2003b) conceptualisation of network competence does appear useful. It is conceivable that a firm's competence for managing in networks is reliant upon

- the tasks it needs to execute across all relationships,

- the tasks specific to certain relationships,

- the special qualifications necessary to execute these tasks, and

- the social qualifications necessary to execute these tasks.
In contrast, the question may be asked: Is that enough? Furthermore, by adapting a broader resource-based theory perspective researchers might also consider network capabilities (Walter et al., 2006) which originate with the notion of "marketing assets" (Hooley et al., 2001; Hooley et al., 2005) and include customerbased assets, distribution or supply chain-based assets, internal assets and alliance-based assets. Measuring network capabilities might provide additional insights and identify the relationship or overlap with network competence.

The measure of network competence presented in this study seems to hold for both for-profit and not-for-profit firms. This result is treated with some scepticism as the number of not-for-profit firms in the sample is very small ( 8 per cent). Investigating such a proposition might yield new information and may well benefit for-profit firms. Similarly, the absence of a difference in the measurement of network competence between private and public firms, as well as the nationality of firms, might suffer from the same restriction, but contains fertile research grounds. Encouragingly, the fact that no significant difference between primary economic sectors was found demonstrates the power of the scale for use in cross-sectional research designs. This result should also be treated with caution because primary sector classifications are defined very broadly and a more refined approach may yield different results. The correlation between network competence and perceived BEE compliance certainly warrants further investigation. In the South African business landscape this is a topic of considerable debate and adding this dimension should further enrich the dialogue. Finally, the measurement of network competence also seems uninfluenced by firm size. This is also encouraging and promotes the use of the scale in a variety of business environments.

In terms of individual factors, the results indicate statistically significant differences in network competence according to managerial function for two of the latent variables in the network competence scale. This should raise some interesting research and managerial questions. While it may also be inherent to a perceptual response, this is consistent with the 
findings suggested by studies on network pictures and network insight (Henneberg, et al., 2006; Oberg et al., 2007; Mouzas et al., 2008). Such a differentiation may well attract further research attention as researchers seek to understand how different professionals perceive the firm and its position in an interconnected environment. A potentially significant contribution of this study is that it partially supports the finding of De Klerk and Kroon (2008) in terms of the observed difference in measurement for older (46-50 years) and younger respondents. They (De Klerk and Kroon) find a medium effect (based on practical significance) between younger and older respondents regarding the preference for a smaller, rather than larger, number of "participants" in a network, while in this study the difference was observed for relationship-specific tasks. This result suggests that managers might need to be sensitive to age when assigning managerial responsibilities for network relationships. Clearly, on face value, this seems highly controversial and warrants further investigation. It is also encouraging to note no differences based on managerial level, ethnicity and gender in the measure of network competence. Again, it suggests that the scale is not influenced by these variables and provides further support for its application, but sample limitations dictate that researchers and practitioners must be careful to disregard these variables. Finally, the same limitation applies to the observed differences between South African and non-South African respondents. However, at the same time it supports the value of having multi-national management teams and it seems that, from a network perspective, South African firms may benefit from such diversity.

\section{9}

\section{Limitations}

The contribution of this study is limited to its specific objectives. In addition, it is also limited to some methodological restrictions. Key among these is the use of a non-probability sampling technique. Even though a perfect probability sample for business-to-business managers might be very difficult to develop, future studies on network competence should aim to achieve this.
A random sample will increase the ability to generalise the findings, and the factors that may or may not impact on the measurement could be isolated with more confidence. In addition, and consistent with the De Klerk and Kroon (2008) study, this study also employs a cross-sectional design. Such a design might increase the ability to generalise findings across various industry and firm types, but it often does not yield the richness of a longitudinal research design. Herein lies a further problematic issue often associated with scale refinement studies, namely that the NetCompTest scale cannot be treated as an "off-the-shelf" tool ready to be used. The scale might need adjustment to the various contexts for which it is intended.

Finally, it also appears that network competence is in need of conceptual refinement. The paper cites many areas of questionable conceptualisation and these will have to withstand the test of time as a critical mass of literature in a South African context develops. Notable amongst these are the cited limitations of network theory to be seamlessly integrated with resource-based theory (Baraldi et al., 2007) and its consequent limitations to contribute to competitive strategy. Opening this dialogue and expanding research to include issues such as the linkage between network competence, network capabilities and firm performance may reveal new and interesting insights for researchers, and may better prepare practitioners to formulate and implement strategy in complex buyer-seller networks.

\section{Endnotes}

1. The author wishes to thank the SAJEMS reviewers for their substantial contribution to this paper. Their commitment, dedication and professionalism went far beyond the boundaries of duty.

2. They define Emerging Markets broadly as countries in which PPP-adjusted GDP per capita (converted to U.S. dollar and smoothed for three-year currency fluctuations) is equal to or less than the highest-ranked country classified as "middle income" by the World Bank. They use GDP per capita as opposed to gross national income, because GDP excludes remittances from other countries, and they argue that GDP is a better measure of domestic growth and economic 
performance and hence more useful for the purposes of most marketers.

3. In this section the reference to firm(s) implies respondents from those firms where applicable. No aggregation of responses was done at firm level.

\section{References}

ACHROL, R.S. \& KOTLER, P. 1999. Marketing in the network economy. Journal of Marketing, 63: 146-163. ANDERSON, E.W., FORNELL, C. \& LEHMANN, D.R. 1994. Customer satisfaction, market share, and profitability: findings from Sweden. Journal of Marketing, 56: 53-66.

ATUAHENE-GIMA, K. 2005. Resolving the capability-rigidity paradox in new product innovation. Journal of Marketing, 69: 61-83.

AWAUH, G. B. 2001. A firm's competence development through its network of exchange relationships. Journal of Business and Industrial Marketing, 16: 274-599.

BAGOZZI, R.P. 1994. Structural equation models in marketing research: basic principles. In BAGOZZI, R.P. (ed.) Principles of marketing research. Oxford: Blackwell.

BAGOZZI, R.P. \& FOXALL, G.R. 1995. Construct validity and generalizability of the kirton adaptioninnovation inventory. European Journal of Personality, 9: 185-206.

BANDYOPADHYAY, S. 2001. Competitiveness of foreign products as perceived by consumers in the emerging Indian market. Consumer Research, 11: 53-64.

BARALDI, E., BRENNAN, R., HARRISON, D., TUNISINI, A. \& ZOLKIEWSKI, J. 2007. Strategic thinking and the IMP approach: a comparative analysis. Industrial Marketing Management, 36: 879-894. BATT, P.J. \& PURCHASE, S. 2004. Managing collaboration within networks and relationships. Industrial Marketing Management, 33: 169-174. BURGESS, S.M. 2003a. Within-country diversity: Is it the key to South Africa's future Prosperity? Convergence, 4: 1-6.

BURGESS, S.M. 2003b. Within-country diversity: Is it the key to South Africa's prosperity in a changing world? International Journal of Advertising, 22: 157-182. BURGESS, S.M. \& STEENKAMP, J-B. E.M. 2006. Marketing renaissance: how research in emerging markets advances marketing science and practice. International Journal of Research in Marketing, 23: 337-356.

BUSH, V.D., ROSE, G.M., GILBERT, F. \& INGRAM, T.N. 2001. Managing culturally diverse buyer-seller relationships: the role of intercultural disposition and adaptive selling in developing intercultural communication competence. Journal of the Academy of Marketing Science, 29: 391-404.

CARROLL, S.J. \& GILLEN, D.J. 1987. Are the classical management functions useful in describing managerial work? Academy of Management Review, 12, $38-51$

CAVUSGIL, S.T. 1997. Measuring the potential of emerging markets: an indexing approach. Business Horizons, 40: 87-91.

CHIN, W.W. 1998. Issues and opinion on structural equation modeling. Management Information Systems Quarterly, 22: 1-11.

COOPER, D.R. \& SCHINDLER, P.S. 2006. Business research methods. New York: McGraw-Hill. CRONBACH, L. 1951. Coefficient alpha and the internal structure of tests. Psychometrika, 16: 297-334. DE KLERK, S. \& KROON, J. 2008. Business networking relationships for business success. South African Journal of Business Management, 39: 25-35. DRAULANS, J., DEMAN, A.-P. \& VOLBERDA, H.W. 2003. Building alliance capability: management techniques for superior alliance performance. Long Range Planning, 36: 151-166.

DUYSTERS, G., DE MAN, A-P. \& WILDEMAN, L. 1999. A network approach to alliance management. European Management Journal, 17: 182-187. DYER, J.H. \& HATCH, N.W. 2006. Relation-specific capabilities and barriers to knowledge transfers: creating advantage through network relationships. Strategic Management Journal, 27: 701-710.

EDMUNDSON, E.W. \& KOCH, W.R. 1993. A facet analysis approach to content and construct validity. Educational and Psychological Measurement, 53: 351-368.

FANG, E., PALMATIER, R.W., SCHEER, L.K. \& LI, N. 2008. Trust at different organizational levels. Journal of Marketing, 72: 80-98.

FARRELL, M.A. \& OCZKOWSKI, E. 1997. An analysis of the MKTOR and MARKOR measures of market orientation: an Australian perspective. Marketing Bulletin, 8: 30-40.

FINN, A. \& KAYANDE, U. 1997. Reliability assessment and optimization of marketing measurement. Journal of Market Research, 34: 262-275. FORD, D., BERTHON, P., BROWN, S.W., GADDE, L-E., HAKANSSON, H., NAUDE, P., RITTER, T. $\&$ SNEHOTA, I. 2005. The business marketing course: managing complex networks. Chichester: Wiley. FORD, D., GADDE, L., HÅKANSON, H., LUNDGREN, A. \& SNEHOTA, I. 1998. Managing business relationships. Chichester: Wiley. FORD, D., GADDE, L., HAKANSSON, H. \& SNEHOTA, I. 2004. Managing networks. IMP. 
FORD, D. \& SAREN, M. 1996. Technology strategy for business. London: Thompson.

FORSGREN, M., HOLM, U. \& JOHANSON, J. 2005. Managing the embedded multinational. Cornwall: MPG Books.

FOTTLER, M.D. 1981. Is management really generic? Academy of Management Review, 6, 1-12.

FREYTAG, P.W. \& RITTER, T. 2005. Dynamics of relationships and networks - creation, maintenance and destruction as managerial challenges. Industrial Marketing Management, 34: 644-647. GEMUNDEN, H. G., RITTER, T. \& WALTER, A. 1997. Relationships and networks in international markets. Oxford: Pergamon.

GOLFETTO, F. \& GIBBERT, M. 2006. Marketing competencies and the sources of customer value in business markets. Industrial Marketing Management, 35 : 904-912.

GWENDOLYN, K.L. 2007. The significance of network resources in the race to enter emerging product markets: the convergence of telephony communications and computer networking, 1989-2001. Strategic Management Journal, 28: 17-37.

HAIR, J.F., BLACK, W.C., BABIN, B., ANDERSON, R.E. \& TATHAM, R.L. 2006. Multivatiate data analysis. Upper Saddle River: Prentice Hall.

HAIR JR., J.F., MONEY, A., SAMOUEL, P. \& PAGE, M. 2007. Research methods for business. Chichester: Wiley.

HÅKANSON, H., JOHANSON, J. \& WOOTZ 1976. Influence tactics in buyer- seller processes. Industrial Marketing Management, 4(6): 319-332.

HÅKANSSON, H. 2006. Business relationships and networks: consequences for economic policy. The Antitrust Bulletin, 51: 143-150.

HÅKANSSON, H. \& FORD, D. 2002. How should companies interact in business networks? Journal of Business Research, 55: 133-139.

HAMEL, G. \& HEENE, A. 1994. Competence-based competition. New York: Wiley.

HANSEN, M.T. 1999. The search-transfer problem: the role of weak ties in sharing knowledge across organization subunits. Administrative Science Quarterly, 44: 82-111.

HARLAND, C.M. \& KNIGHT, L.A. 2001. Supply network strategy: role and competence requirements. International Journal of Operations \& Production Management, 21: 476-489.

HARMSEN, H. \& JENSEN, B. 2004. Identifying the determinants of value creation in the market: A competence-based approach. Journal of Business Research, 57: 533-547.

HEDAA, L. \& RITTER, T. 2004. Business relationships on different waves: paradigm shift and marketing orientation revisited. Industrial Marketing Management, 34: 714-721.

HENNEBERG, S.C., MOUZAS, S. \& NAUDE, P. 2006. Network pictures: concepts and representations. European Journal of Marketing, 40: 408-429.

HITT, M.A. \& IRELAND, R.D. 1986. Relationships among corporate level distinctive competencies, diversification strategy, corporate strategy and performance. Journal of Management Studies, 23: 401-416.

HOOLEY, G.J., GREENLEY, G.E., CADOGAN, J.W. \& FAHY, J. 2005. The performance impact of marketing resources. Journal of Business Research, 58 : 18-27.

HOOLEY, G.J., GREENLEY, G.E., FAHY, J. \& CADOGAN, J.W. 2001. Market-focused resources, competitive positioning and firm performance. Journal of Marketing Management, 17: 503-520.

HUNT, S.D. \& LAMBE, C.J. 2000. Marketing's contribution to business strategy: marketing orientation, relationship marketing and resourceadvantage theory. International Journal of Management Reviews, 2: 17-44.

IACOBUCCI, D. \& HOPKINS, N. 1992. Modeling dyadic interactions and networks in marketing. Journal of Marketing Research (JMR), 29: 5-17.

JARVIS, C.B., MACKENZIE, S.B. \& PODSAKOFF,

P.M. 2003. A critical review of construct indicators and measurement model misspecification in marketing and consumer research. Journal of Consumer Research, 30 : 199-218.

JOHNSTON, WJ., PETERS, L.D. \&

GASSENHEIMER, J.B. 2006. Questions about network dynamics: characteristics, structures, and interactions. Journal of Business Research, 59: 945654.

JÖRESKOG, K.G. \& SÖRBOM, D. 1993. LISREL 8: A user's reference guide. Chicago: Scientific Software International.

JÖRESKOG, K.G. \& SÖRBOM, D. 1999. Structural equation modeling with the SIMPLIS command language. Lincolnwood: Scientific Software International.

KHANNA, T., PALEPU, K.G. \& SINHA, J. 2005. Strategies that fit emerging markets. Harvard Business Review, 83: 63-76. KLEMZ, B.R., BOSHOFF, C. \& MAZIBUKO, N-E. 2005. Emerging markets in black South African townships: small local independently owned versus large national retailers. European Journal of Marketing, 40: 590-610.

LEEK, S., NAUDE, P. \& TURNBULL, P. W. 2003. Interactions, relationships and networks in a changing world. Industrial Marketing Management, 32: 87-90. 
LICHTENSTEIN, S. \& DADE, P. 2007. The shareholder value chain: values, vision and shareholder value creation. Journal of General Management, 33: 15-31.

LOCKE, K.D. 2000. Circumplex scales of interpersonal values: reliability, validity, and applicability to interpersonal problems and personality disorders. Journal of Personality Assessment, 75: 249-267. LUCAS, R.E., DIENER, E. \& SUH, E. 1996. Discriminant validity of well-being measures. Journal of Personality and Social Psychology. 71: 616-628. MADDEN, T.J., DILLON, W.R. \& TWIBLE, J.L. 1986. Construct validity of attitude toward the ad: an assessment of convergent/discriminant dimensions. In OLSON, J. \& SENTIS, K. (eds.). Advertising and Consumer Psychology. New York: Praeger.

MCDANIEL, C.D. \& GATES, R. 2006. Marketing

Research Essentials. Hoboken: Wiley.

MCGEE, J., THOMAS, H. \& WILSON, D. 2005.

Strategy: analysis \& practice. New York: McGraw-Hill. MESQUITA, L.F., ANAND, J. \& BRUSH, T.H. 2008. Comparing the resource-based and relational views: knowledge transfer and spillover in vertical alliances. Strategic Management Journal, 29: 913-941.

MOLLER, K. \& RAJALA, A. 2007. Rise of strategic nets: "New modes of value creation". Industrial Marketing Management, 36: 895-908.

MÖLLER, K.K. \& HALINEN, A. 1999. Business relationships and networks: managerial challenge of network era. Industrial Marketing Management, 29: 413-427.

MOUZAS, S., HENNEBERG, S. \& NAUDÉ, P. 2008. Developing network insight. Industrial Marketing Management, 37: 167-180.

NAIRN, A., EDE, L. \& NAUDE, P. 2004. Multivariate statistics in industrial marketing management: A practitioner tool kit. Industrial Marketing Management, 33: 573-582.

NETEMEYER, R.G., KRISHNAN, B., PULLIG, C., WANG, G., YAGCI, M., DEAN, D., RICKS, J. \& WIRTH, F. 2004. Developing and validating measures of facets of customer-based brand equity. Journal of Business Research, 57: 209-224.

NETERMEYER, R.G., DURVASULA, S. \& LICHTENSTEIN, D. 1991. A cross-national assessment of the reliability and validity of the CETSCALE. Journal of Marketing Research, 28: 320-327.

OBERG, C., HENNEBERG, S.C. \& MOUZAS, S. 2007. Changing network pictures: Evidence from mergers and acquisitions. Industrial Marketing Management, 36: 926-940.

OERLEMANS, L.A.G. \& PRETORIUS, M.W. 2006. Determinants of innovation in South Africa.
An exploratory analysis using firm-level data. South African Journal of Science, 102(11/12): 589-593. PALMATIER, R.W., DANT, R.P. \& GREWAL, D. 2007. A comparative longitudinal analysis of theoretical perspectives of interorganizational relationship performance. Journal of Marketing, 71: 172-194.

PALMER, A. 2001. Co-operation and collusion: making the distinction in marketing relationships. Journal of Marketing Management, 17: 761-784. PARKHE, A., WASSERMAN, S. \& RALSTON, D.A. 2006. Introduction to special topic forum new frontiers in network theory development. Academy of Management Review, 31: 560-568.

PFEFFER, J. \& SALANCIK, G.R. 2003. The external control of organizations: a resource dependence perspective. Stanford University Press.

RITTER, T. 1999. The networking company: antecedents for coping with relationships and networks effectively. Industrial Marketing Management, 28: 467-479.

RITTER, T. \& GEMÜNDEN, H.G. 2003a.

Interorganizational relationships and networks: an overview. Journal of Business Research, 56: 691-697. 2003b. Network competence: its impact on innovation success and its antecedents. Journal of Business Research, 56: 745-755.

2004. The impact of a company's business strategy on its technological competence, network competence and innovation success. Journal of Business Research, 57: 548-556.

RITTER, T., WILKINSON, I.F. \& JOHNSTON, W.J. 2002. Measuring network competence: some international evidence. Journal of Business and Industrial Marketing, 17: 119-138.

2004. Managing in complex business networks. Industrial Marketing Management, 33: 175-183.

ROSS, W. T. \& ROBERTSON, D.C. 2007. Compound relationships between firms. Journal of Marketing, 71: 108-123.

ROSSITER, J.R. 2002. The C-OAR-SE procedure for scale development in marketing. International Journal of Research in Marketing, 19: 305-335.

RUEKERT, R.W. \& CHURCHILL Jr, G.A. 1984. Reliability and validity of alternative measures of channel member satisfaction. Journal of Marketing Research, 21: 226-233.

SANCHEZ, R. \& HEENE, A. 2004. The new strategic management: organization, competition, and competence. New York: Wiley.

SAVOLAINEN, R. 2002. Network competence and information seeking on the internet: from definitions towards a social cognitive model. Journal of documentation, 58: 211-236. 
SIRMON, D.G., HITT, M.A. \& IRELAND, R.D. 2007. Managing firm resources in dynamic environments to create value: Looking inside the black box. Academy of Management Review, 32: 273-292. SOWINSKI, L.L. 2000. Emerging markets offer profit potential. World Trade, 13: 6-31.

STACEY, A.G. 2005. The reliability and validity of the item means and standard deviations of ordinal level response data. Management Dynamics, 14: 2-25.

STEENKAMP, J-B. E.M. \& BURGESS, S.M.

2002. Optimum stimulation level and exploratory consumer behavior in an emerging consumer market. International Journal of Research in Marketing, 19: 131-150.

STEENKAMP, J.-B. E.M. \& TRIJP, H.C.M.V. 1997.

Attribute elicitation techniques in marketing research: a comparison of three methods. Marketing Letters, 8: 153-165.

SWEENEY, J.C., HAUSKNECHT, D. \& SOUTAR, G.N. 2000. Cognitive dissonance after purchase: a multidimensional scale. Psychology and Marketing, 17: 369-385.

VAN DER MERWE, R., BERTHON, P., PITT, L. \& BARNES, B. 2007. Analysing "theory networks": identifying the pivotal theories in marketing and their characteristics. Journal of Marketing Management, 23: 181-206.

WAlTER, A., AUER, M. \& RITTER, T. 2006. The impact of network capabilities and entrepreneurial orientation on university spin-off performance. Journal of Business Venturing, 21: 541-567.

WALTER, A., RITTER, T. \& GEMÜNDEN, H.G. 2001. Value creation in buyer-seller relationships theoretical considerations and empirical results from a supplier's perspective. Industrial Marketing Management, 30: 365-377.

WERNERFELT, B. 1989. From critical resources to corporate strategy. Journal of General Management, 14: 4-12.

WILKINSON, I. \& YOUNG, L. 2002. On cooperating: firms, relations and networks. Journal of Business Research, 55: 123-132.

WITZEL, M. 2002. Cooperative strategy: economic, business and organizational issues/strategy and performance: competing through competences/ strategy and performance: getting the measure of your business/ strategy and performance: creating a winning business formula. Journal of General Management, 28: 88-91.

WRIGHT, M., FILATOTCHEV, I., HOSKISSON, R.E. \& PENG, M.W. 2005. Strategy research in emerging economies: challenging the conventional wisdom. Journal of Management Studies, 42: 1-3. ZARHA, S.A. \& GEORGE, G. in HITT, M.A., IRELAND, R.D., CAMP, A.M. \& SEXTON, D.L. 2002. Strategic entrepreneurship: creating a new mindset. Oxford: Blackwell. 